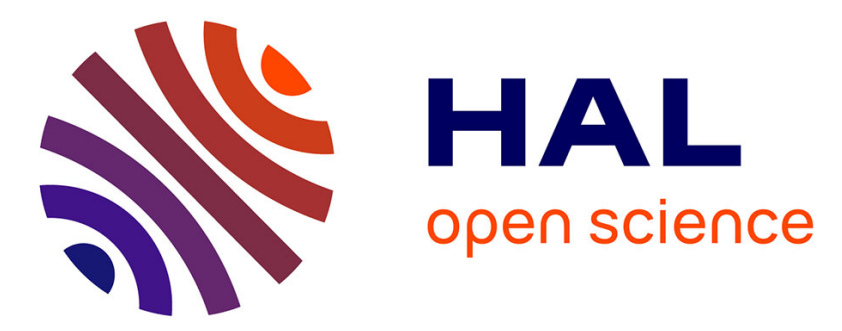

\title{
The trajectories leading to supporting at a distance: the Olympique de Marseille case study
}

\author{
Ludovic Lestrelin, Loïc Sallé, Jean-Charles Basson
}

\section{To cite this version:}

Ludovic Lestrelin, Loïc Sallé, Jean-Charles Basson. The trajectories leading to supporting at a distance: the Olympique de Marseille case study. European Journal for Sport and Society, 2006, 3 (2), pp.125-141. 10.1080/16138171.2006.11687785 . hal-02177315

\section{HAL Id: hal-02177315}

\section{https://hal-normandie-univ.archives-ouvertes.fr/hal-02177315}

Submitted on 8 Jul 2019

HAL is a multi-disciplinary open access archive for the deposit and dissemination of scientific research documents, whether they are published or not. The documents may come from teaching and research institutions in France or abroad, or from public or private research centers.
L'archive ouverte pluridisciplinaire HAL, est destinée au dépôt et à la diffusion de documents scientifiques de niveau recherche, publiés ou non, émanant des établissements d'enseignement et de recherche français ou étrangers, des laboratoires publics ou privés. 
archives-ouvertes

\title{
The trajectories leading to supporting at a distance: the Olympique de Marseille case study
}

\author{
Ludovic Lestrelin, Loïc Sallé, Jean-Charles Basson
}

\section{To cite this version:}

Ludovic Lestrelin, Loïc Sallé, Jean-Charles Basson. The trajectories leading to supporting at a distance: the Olympique de Marseille case study. European Journal for Sport and Society, 2006, 3, pp.125 - 141. hal-02177315

HAL Id: hal-02177315

https://hal-normandie-univ.archives-ouvertes.fr/hal-02177315

Submitted on 8 Jul 2019

HAL is a multi-disciplinary open access archive for the deposit and dissemination of scientific research documents, whether they are published or not. The documents may come from teaching and research institutions in France or abroad, or from public or private research centers.
L'archive ouverte pluridisciplinaire HAL, est destinée au dépôt et à la diffusion de documents scientifiques de niveau recherche, publiés ou non, émanant des établissements d'enseignement et de recherche français ou étrangers, des laboratoires publics ou privés. 


\title{
The trajectories leading to supporting at a distance: the Olympique de Marseille case study
}

\author{
Ludovic Lestrelin, Loïc Sallé and Jean-Charles Basson \\ University of Rouen, France \\ University Lille II, France \\ University Paul Sabatier - Toulouse III, France
}

\begin{abstract}
This article aims to define the dynamics leading individuals to get involved in a passion we chose to name "supporting at a distance". This practice involves actively supporting a football team that does not belong to one's own town or region. The study relies on to the concept of "career", directly stemming from the Chicago sociological tradition and studies on militancy. This concept will help to understand how someone starts supporting a club while living several hundreds of kilometres away. We therefore suggest analysing the careers of football supporters by focusing on the notion of rewards of the militant engagement, and by emphasizing the weight of "biographical accidents" in the construction of individual trajectories.
\end{abstract}

Key words: career, engagement, football, rewards, supporters.

\section{Introduction}

What kind of logic can push an individual to become involved in supporting at a distance? This form of passion involves supporting a football team remote from one's own place of residence (sometimes several hundreds or even thousands of kilometres away). Supporting at a distance thereby designates an identification and mobilization process with no local attachment to football clubs: the territorial anchorings of teams and fans are different (Lestrelin, 2006; Lestrelin \& Basson, 2004). This practice is not limited to following the club through the media; it also admits modalities of hard-line support, such as regularly following the team to go to the games at home and away.

The article begins with a discussion of the previous studies on football supporters. Supporting at a distance has widely been left aside. Some answers have been formulated to explain the identifications and the forms of distance support. These studies focus on the general reasons that could be at the origin of this phenomenon. But they overtook the dynamics that push some individuals to become involved in this practice.

Consequently, how can we understand the development of distance identification and mobilization? In the second part of the article, we suggest that, as for other types of engagement, it is necessary to emphasize that one becomes a supporter, little by little, for a long or a short period, according to a context or circumstances that are linked to personal trajectories. Becoming a supporter can be analysed as a "career", as Crawford (2003), Jones (2000) and Marsh (1978) have postulated. It is possible to consider engagement in a group of supporters as a social activity - framed in space 
and time, going through different stages of enrolment, maintaining the commitment, and defection - by returning to the inheritance of the Chicago sociological tradition (Becker, 1963; Hughes, 1996b). We postulate that the notion of "militancy rewards" must be at the centre of the reflection, in order to untangle the strands of the careers of supporters. The personal trajectories must indeed be linked to the perceived benefits of being affiliated to a group of supporters. We can therefore put forward the hypothesis that the construction of individual trajectories depends on the variations of the rewards expected. Nevertheless, we must surely look at another core dimension of engagement. Participation in supporting at a distance should also be considered according to the weight of "biographical breaks" that individuals have experienced in other spaces of their life, be it in the emotional, family or professional spheres.

These hypotheses have been tested in a particular empirical field. In France, as in other countries, many football clubs are able to mobilize passions at a distance. For example, Olympique de Marseille (OM) has a particularly large number of supporters in different French regions, and also in other countries. A group based in Normandy (more than 900 kilometres from Marseilles) of roughly one hundred members travels every week when OM has a game. The third part of this article aims to expose the modalities of the attachment to $\mathrm{OM}$ and the trajectories leading these individuals to organize their lives according to the team despite the distance.

\section{Modes of membership for football club supporters}

As Goksoyr and Hognestad $(1999,206)$ noticed, many works postulate "that identity in football is linked to experiences of conflict and emotion, be it at a local or national universe". There are indeed two characteristics that emerge from previous studies of football supporters. First, the popular craze for football takes its strength from both the reinforcement of collective identities and the sublimation of territorial stakes it enables. Football teams are considered as an extension of the community. Bromberger in his study of Marseilles, Naples, and Turin insists on the idea that football clubs represent a "local style" $(1995,15)$. After analysing the form of game played on the pitch, the style of management adopted by the leaders, and the kind of supporting that is approved in the stands, he concludes that the style of a team presents itself as the affirmation of a local identity. In this way, "for the young supporter, progressively discovering the properties of this local style is a kind of emotional and social incorporation of his town or region's values" (Bromberger, 1995, 122). The identification with the team will arise from the closeness and the sharing of a singular history made of the values and the imaginary that are specific to the community in which the club is rooted.

The second obvious characteristic is that the world of football supporters is considered as a space for conflicts and struggles between partisan groups (Basson \& Nuytens, 2001; Bromberger, 1995). Considering that the clubs symbolize singularities and idiosyncrasies, they are de facto seen as expressive supports for states of tension, and ethnical, religious or social antagonisms. According to a large number of authors, the most demonstrative and turbulent groups of supporters (called ultra in Italy, where 
they appeared in the 1970s) push these conflicts to the extreme (Dunning et al., 2002; Roversi \& Balestri, 2000). For Bromberger:

One ought to search the origin of this overstatement within and without the logic of the game: inside, in the outcome of the oppositional nature of confrontations that permanently needs more discredit of the adversary; outside, in a movement of territorial and ethnical identities reaffirmation, relaying universalizing ideologies at the end of this century $(1995,24)$.

In sum, the fact that the differences are becoming increasingly confused seems to be the condition for the exacerbation of rivalries. In Italy, for example, fans of Naples have never been as similar to those of Juventus Turin in terms of their way of life, but they probably have never felt further apart from one another. Football supporters would withdraw on a "parochial patriotism". Though the studies in question are rich and pertinent, they omit some activities. Indeed, there are numerous supporters at a distance who take part in the support of a club by proxy, in spite of the geographical distance separating them from the team. Thus, supporting at a distance designates a complex identification and mobilization process. It comes in a variety of forms, whether it means closely following the team through press and television, or purchasing shirts, scarves, and other products promoting the glory of the supported team. In addition to the symbolic claim for the attachment to the club, there are also hard-line modes of support, such as the group following the team to see both home games and away games. Supporting at a distance can thus include feelings of empathy and assimilation towards the club's regional characteristic identity and cultural features. Nick Hornby showed in a literary form how his passion for Arsenal appeared as a quest of identity, even if it sometimes meant pretending:

Ever since I have been old enough to understand what it means to be suburban I have wanted to come from somewhere else, preferably North London. I have already dropped as many aitches as I can - the only ones left in my diction have dug themselves too far into definite articles to be winkled out - and I use plural verb forms with singular subjects whenever possible. This was a process that began shortly after my first visit to Highbury (...) $(1994,40)$.

Though they may seem to lack openness at first sight, the supporter territories increasingly accept exchanges, meetings and compromises. This latter aspect leads us to wonder with Signorelli (1994) whether they still symbolize the town of the football club.

The various mutations of the football world have been the subject of much research, especially in Great Britain. The transformation in the sociological composition of the public has generated an abundant literature (among others, Giulianotti, 1999; Redhead, 1997; Williams, 2001). Many works deal with the spread of television (Redhead, 1997), the impact of the commercialization of football on supporters 
(Brown, 1998), the management of hooliganism by the police (Tsoukala, 1995) or even the Europeanization of teams and competitions (Smith, 2001). Would supporting at a distance be the only blind spot of research? The phenomena of affiliation to a distant team have attracted the attention of some authors.

Some answers have been formulated and three types of arguments have been used to explain supporting at a distance. The football clubs' past and their "historical" dimension are touched on first. They justify the diffuse attachment of numerous militants. The globalization of football, the flows of capital, labour (mobility of players, for example) and culture contribute to the dispersal of groups of fans, too (Ben-Porat \& Ben-Porat, 2004; Giulianotti, 1999; Hognestad, 2003). Moreover, the media coverage of football through television and now the Internet is an important influence (Sandvoss, 2003). In Norway, the passion for English teams began with the interest in British football shown by the Norwegian sports press (Goksoyr \& Hognestad, 1999). In the past, football fans identified with the team that they saw "for real" in the stadium. Today, fans are able to watch live matches from foreign clubs across the world. It is the case, for instance, in Israel, where many spectators follow a British or Italian club (Ben-Porat, 2000). More and more pubs specialize in the broadcasting of live matches and thus become gathering places for supporters at a distance. Lastly, migratory movements are also seen as a determinant of passion at a distance (Bromberger, 1995; Mignon, 1998). In this case, supporting at a distance would be a way of perpetuating the link with the country of origin. For example, Italian, Portuguese, Spanish or Greek clubs represent "symbols of uniting" for numerous expatriates dispersed all over Europe, these countries having known powerful migratory movements in different periods. In Malta, the historical, cultural and genealogical ties with Great Britain are fundamental to explaining the identification with many English football clubs (Armstrong \& Mitchell, 1999). Nevertheless, though these explanations can be pertinent and cast an initial light on the general mechanisms of the faraway affiliation to football clubs, they also pose several problems. On the one hand, they consider supporters at a distance as exiled natives who would thereby be disposed to support the club representing their roots. But no details on the trajectories of engagement back up this hypothesis. On the other hand, the transition to mobilization is never questioned. In several European countries, many groups of supporters at a distance organize journeys to follow the teams and attend the games. Why don't these people stay in front of their television? The arguments used locate the root of supporting at a distance within the existence of a strong social demand, stemming from the football clubs' accumulation of successes, which would naturally generate the proliferation of groups embodying individual affiliations. These arguments are also reminiscent of a conception that mechanically links the development of groups of supporters at a distance to the increase of support through media (radio, press, television, and, more recently, the Internet) providing the clubs with a better national and international visibility than before. To cut a long story short, the conditions and the forms of transition remain opaque, and many questions remain unanswered. Who gets involved in supporting at a 
distance? How does the attachment to a club abroad progressively build up? Why do people engage?

\section{The concept of career and the sociology of militancy}

To answer these questions, it seems essential for us to consider supporting at a distance as a social activity inscribed in a specific temporality with different stages: first, identification with the club and informal militancy (watching games on television, reading the specialized press), then enrolment in a group of supporters and stronger militancy (notably regular travels to see games at home and away), affirmation of the engagement, undertaking of responsibilities, defection etc. Such would be the typical evolution of positions that could characterize supporting at a distance. Nevertheless, we believe that these positions are not fixed, though this linear and sequential reading of the engagement still informs representations and many academic publications (as Crawford showed in 2003). The schematic opposition between the spectator and the supporter is a striking example. Supporting at a distance is not a stable state. The paths are neither rigid nor linear, because they induce successive readjustments and permanent negotiations. Trajectories are to be considered as dynamic processes, in which phases of acceleration and changes alternate with stagnation, inertia, and regression. Thus, in order to understand the mobility affecting individual trajectories, it seems pertinent to use the idea of "supporters' careers", directly borrowed from interactionist sociology.

The concept of career owes its acceptance to Becker, though Hughes (1996b) originally thought it up for his research on professions. By studying marijuana smoking and jazz musicians, Becker contributed to spread the concept to all phenomena of engagement. Its entire relevance resides in Hughes's definition of a career as summarized by Becker:

Objectively (...) a series of statuses and clearly defined offices (...), typical sequences of position, achievement, responsibility, and even of adventure (...). Subjectively, a career is the moving perspective in which the person sees his life as a whole and interprets the meaning of his varied attributes, actions, and the things which happen to him $(1963,102){ }^{1}$

Not only does the concept of career allow us to focus on the events that give rhythm to the trajectory of an individual, but it also turns our attention to the way they are subjectively interpreted. Whenever applied to supporting at a distance, the concept of career allows us to understand how behaviour, attitudes, and choices are influenced by past positions, and condition in turn future positions at each stage of one's biography. The predisposition to supporting at a distance, the putting this into practice, the differentiated and time-changing forms of engagement, and the disaffiliations have all been simultaneously questioned and thoroughly studied. But researchers have given 
little credit to this analytical frame of fandom. Few authors have centred their analyses on the dynamic aspect of such a practice (Crawford, 2003; Jones, 2000; Marsh, 1978).

This is not the case in militancy sociology. For the past ten years, numerous works have taken this orientation in order to study the engagement in varied political and associative movements. The work by Fillieule (2001; Broqua \& Fillieule, 2001) seems particularly rich and stimulating by the approaches it suggests. First of all, the notion of rewards (Gaxie, 1977) - i.e. the benefits the individuals think they will obtain through their engagement - becomes central. There can be two types of rewards. They can be actually or potentially material rewards: one can obtain a job with responsibility, and benefit from reduced tariffs and varied services. The second type concerns symbolic rewards, i.e. all the psychologically status-enhancing satisfactions one can get by participating in a collective action: social capital, notoriety, self-esteem, sociability, solidarity, and camaraderie. Rewards are not only objective elements: the actors subjectively experience them. In other words, the actors may or may not be conscious of them. They are therefore infinitely changing: what some will consider as a benefit, others will consider as a cost, and vice versa. Neither are they only anticipated. During an action, one may discover the virtues and the advantages of being engaged. In other words, no one has the same perception of the situation or of the costs and benefits of an action.

But according to Fillieule (2001), the notion of rewards makes sense only if one considers the individual as living in varied social worlds. As Hughes emphasizes, "there are many careers in one life" that occur simultaneously or successively (1996b, 176). To capture fully the reasons for engagement in an activity, we must widen the focus: even if the supporter is very active, he is more than just a supporter. In sum, he evolves in a plurality of social universes that can match or clash (Strauss, 1993). Considering these spaces are always in connection with (or against) one another, we should not simply stop at what is directly linked to the sphere of supporter activities, but try to enlarge the vision to encompass the other spaces in which the individuals evolve (Lahire, 2001).

The individual receives very different rewards according to these social spaces (professional world, love life, family and sociability spaces, sport life, etc.). This can simply be explained by the fact that each of these careers is marked by numerous hazards, incidents, irregularities and other unexpected elements that Hughes (1996a) calls "turning points". These critical moments in the individual biography seem fundamental to us. Thus, we suggest that the professional difficulties (a suddenly darkened horizon or the loss of a job) can generate at a specific moment the will to become involved in an activity such as supporting where one will be able to prove the competences that were dormant until then, to obtain some kind of gratitude, to acquire a status-enhancing role or accumulate responsibilities. In the same way, new perspectives and opportunities can have the opposite effect on the type of involvement (settling as a couple, the birth of a child, finding a job or experiencing professional mobility). As was proved by Strauss (1959), the construction of personal trajectories and the durable changes of personality owe much to biographical accidents and the 
changes that occur in the individuals' different careers. We suggest applying these theoretical perspectives to the trajectories of the OM supporters at a distance.

\section{The careers of the OM supporters at a distance}

As far as football is concerned, Marseilles is an exception in France. Stricken by the economic crisis in the 1980s, looked down on by the North of France, Marseilles, as Naples in Italy and Liverpool in Great Britain, makes one with its football club. In this popular and cosmopolitan city, where people enjoy theatrical performances, football is an object of passion. No other French club has so many spectators: 53,000 on average for the 2004-2005 season (whereas the average is about 29,000 for the French championship). OM also mobilizes passions at a distance. It has numerous groups of supporters spread over many French regions. ${ }^{2}$ A group based in Rouen, 900 kilometres from Marseilles, attracted our attention. It was created in 1997 and brought together 107 members in 2004. Seven people in charge share the management of the group. Two leaders (a President and a Vice-President) organize the journeys to see OM play, book the buses, the seats in the stadia, and handle the finances. An editor takes care of the fanzine (Haynes, 1995) while the others are the "socializing agents", inculcating the group's rules and principles into new members.

In order to study how the careers concretely take place, we considered it necessary to use the ethnological method. Thus, we carried out participation observations over three years to grasp the every day activities of supporters at a distance. We had recourse to these observations on twenty-six occasions. We took part in the journeys of the supporters at a distance to follow $\mathrm{OM}$ and in the associative life of the group: raffles, football or pétanque tournaments, dance etc. Twenty biographical interviews were also carried out to give an idea of the variety in the members' trajectories. Moreover, seven former members and three other people were interviewed. Even though they were not involved in the group, they claimed to be supporters of OM. Finally, we gathered and examined some documents, notably the listing of all members since 1999 (with details on members' age, sex, and place of residence) and the fanzines published by the group.

Thus, even if the analysis is based on a sociological study of OM supporters living in Rouen, it seems to us that the reasons for the engagement described, and the possible problems encountered during the activities of the group as well as the kind of involvement are not exclusive to this small sample. On the contrary, the situation of this group and the characteristics of its members invite us to try to shed light on the permanent features in groups of supporters at a distance, in other places and at other times.

2 Our most recent census, carried out in May 2005 reveals that there are 116 groups of supporters at a distance actively and regularly supporting OM. 


\section{Who are the OM supporters at a distance?}

Are the biographical affinities towards Marseilles or the surrounding region pertinent elements to understand why one can become an OM supporter while living hundreds of kilometres away from the club and the town? In other words, is supporting OM in spite of the distance "perpetuating roots" and proceeding to a "return to origins"? The interviews with the supporters from Rouen and the observations revealed that this characteristic only applies to a very small minority (three individuals, to be precise). In the majority of cases, the involvement in supporting at a distance follows another pathway. In fact, twenty-seven out of the thirty people who were interviewed have no biographical link to Marseilles or its region, whether past or present. In other words, the supporters at a distance of $\mathrm{OM}$ are not exiled people originating from Marseilles who wish to continue following the team of their youth. Supporting at a distance contributes to deconstruct the presupposition according to which there would be a natural loyalty towards one's home community. It emphasizes that supporting a club is not systematically linked to a supporter's place of origin.

If the supporters in the observed group are not former inhabitants of Marseilles, then who are they? Normally, an attempt is made to identify the differences between the classical supporter, the one who supports the club of his origins and town of residence, and the distance supporter, or to distinguish the supporters from the spectators. As Crawford (2003) pointed out, this process is too rigid and artificial: it implies the definition of "profiles", even if it means forcing the differences. In our case, the empirical field discourages such initiatives. The experiences and the social roots are indeed varied. Nevertheless, some general aspects enable us to identify some of these supporters' "sociological outlines": they are mostly young males, 25 years of age on average, urban, marked by ordinary backgrounds and a characteristic middleclass life style. But this thumbnail sketch does not express the variety of profiles encountered, which include, for example, secondary school pupils, students, some women, and a company manager. In no way are supporters at a distance sociologically over-determined: there are young people with precarious professional status, but there are also workers who are very well integrated socially, too. One must therefore admit that there is no typical supporter at a distance, though there are typical pathways that are to be reconstructed, according to Becker (1963). First, the trajectories of supporters at a distance show the socializing influence of the family in generating an interest in football. A "football past" is fundamental for the "supporting present". Many of the fans who were observed went to football matches with a male role model (the father in most cases, but sometimes an uncle, a brother or a cousin, too) to follow the local team during their youth. Watching football games on TV was a family ritual. Almost all the members of the group played football when they were children or adolescents. Therefore, these social characteristics are conducive to engagement in such a distancesupporting practice. The interest in football is an important dimension of the identity of the fans in question, and they attach social value to this type of leisure and career. 
Therefore, supporting at a distance is a logical activity, as it is in harmony with the universe of meanings of the individuals involved.

\section{How does the "taste" for OM arise?}

These facts facilitate awareness of propensities to become involved in supporting at a distance. However, it is also important to ascertain why these individuals are fond of OM. For a minority of members (three people, to be precise), the origin of their "taste" for this club is linked to a particularly vivid experience of football that without doubt sealed their attachment to the team. But for most of the people interviewed, their taste for OM progressively arose via television. Two modalities of identification can be singled out. The first is linked to the club's successes. Indeed, many supporters claim to have been given a "buzz" by the club's national achievements and its "European adventures" during OM's successful seasons at the end of the 1980s and in the early 1990s. The second type of identification with OM took the form of a reaction, constructed in a binary way. These "reactive identifications" relate first of all to the symbolic and classic opposition between the capital city and the provinces, the North and the South, the strong rivalry with the Paris-Saint-Germain (PSG) throughout the 1990s. For the supporters at a distance, everything about OM is in contrast to the "polished" capital city team, which is reputed to be affluent and bourgeois. Marseilles, the French "anti capital city", is considered rebellious and crooked, and victim of many stereotypes in the French imagination (Boura, 2001; Cobb, 2001). PSG is perceived as the "establishment club", whereas OM seems to be the symbol of a way of defying the powerful. Therefore, the headline corruption scandal that the club had to deal with in 1993 was a determining factor. OM was relegated to the second division, forbidden to play in the European Cup, and the title of champion of France was taken away from it. This tumultuous episode constituted an identification trigger for those who seemed to recognize in it their own trajectory. Thus, the fact of taking sides with a disqualified club that one considers as being unfairly treated can reflect a wish for individual differentiation and for self-constructing against the general trend. In this case, identification was all the more strongly stimulated because the individuals personally felt the impact of the exclusion and marginalization process that affected the club that affected the club.

The vitality of the attachment pushed some supporters at a distance to take a further step in this career even before entering the group. While they still were "attentive spectators", some of them travelled alone to see OM play. But these trips remained irregular and exceptional. How, then, can we explain the transition from an informal and individual practice to an organized and collective militancy? In order to comprehend this "going into action", we must recognize that following a football team while living far away is a demanding and costly practice. It requires time, a lot of money, and above all a structured organization to guarantee the purchase of tickets on a regular basis. Olivier ${ }^{3}$ (30 year-old male, member since 1999) explains:

The names that are used are fictitious. 
Before becoming a member, I sometimes used to go to see the games in Marseilles with two or three friends. We managed by ourselves. For the tickets, we directly booked with the club by phone. At that time it was still possible to do so. There wasn't the membership system as there is today. So we called, we paid for the tickets by credit card, and we got them on the spot before entering the stadium. Then we used to go to Marseilles by our own means, using a private car. But I travelled only to Marseilles, because it was very hard to obtain tickets for away games.

It seems simpler to give one's support to a collective organization in order to overcome the problems caused by geographical distance. If these constraints motivate a great number of supporters to join the group, as we will see later, they are probably also pertinent to account for the very reasons for the group's birth in Rouen in 1997.

\section{Becoming a member of the group: how does one take the step?}

The transition from an informal to an organized militancy is largely conditioned by the rewards of the engagement. Supporters at a distance have encountered numerous difficulties or frustrations in following OM. So the group is perceived as a space of action which totally fulfils their aspirations: to be able to follow games regularly at home and away, not as a mere spectator, but as a fan involved alongside local supporters. Thus, entering the group means expecting various services, and the group does indeed provide them with tickets for every game, both at home and away. Engagement offers the members of the group the opportunity to benefit from the legitimate means to follow "for real" the games of a club that gave them a "buzz" on television over a number of years. They indicate that they became "active" supporters of OM in order to accomplish this unfulfilled desire. Besides, the members know, from experience, that the group offers opportunities to do things (to go to see a European Cup game along with local fans, for example) which would have been impossible or very difficult if they had acted alone.

Being a member of the group also represents an opportunity to undertake other activities. The trips to Marseilles could include activities such as going to the beach or shopping. Travelling, escaping from Rouen, and discovering new towns therefore also represent constitutive dimensions of this type of engagement. Supporting at a distance could also be viewed as an "individual escape" from everyday life (Hognestad, 2003). But it is mostly the financial advantage that is cited by the interviewees. Sharing the cost of the travel represents an attractive benefit. Some supporters state that they are relieved by the idea of not having any constraints or responsibilities. The idea of "all inclusive" travel emerges in some members' remarks:

I like the fact that the section managers take charge of everything. You have nothing to do, it's stress-free. You are sure that everything is going to be all right. There is going to be no problem. Everything is 
ready, there is nothing to do. If this didn't exist, I wouldn't have been there (Guillaume, 28 year-old male, member since 1999).

Membership of the Rouen group therefore falls into a group of "materializable" rewards. There is much to that. If the rewards implied by membership are less palpable, the effects remain as important, particularly in the member's immediate circle. In some cases, membership is felt to be a way of building a socially status-enhancing identity. Thus, for Pierre (46 year-old male, founder of the group), belonging to a supporters group of a football club such as OM is a source of prestige in his professional environment: "On the building sites they call me the 'Marseillais' [native of Marseilles], because I always wear something showing that I am an OM supporter".

Thus, this practice is part of a quest for recognition. When one chooses to support $\mathrm{OM}$, one chooses a mythical club. And the participation in the life on the terraces where the event occurs means becoming visible to one's personal, family or professional circle. Moreover, the (relative) notoriety and the social and symbolic capital resulting from involvement in supporting at a distance constitute forms of militancy rewards. These are all the more deeply felt because the group is affiliated to a group from Marseilles, whose badge it wears. Being a member of the Rouen section means being recognized and identified as a "real supporter of OM". It is important to supporters at a distance that they must not be suspected of being non-genuine fans.

\section{Active militancy}

The militant activity described can be strongly slowed down or favoured by different social factors. For six of the interviewed people, the variation in the degree of involvement is linked to the evolution of rewards in other spheres of the social life, and notably with the fulfilment of some professional aspirations (such as joining the workforce, finding a new job, obtaining a promotion). Meeting someone (and forming a relationship) can also disrupt involvement in the group. This happened to Stephan (28 year-old male, member since 1997):

Before I met my wife, I could put myself first. Today, it is different. I try to reconcile my passion for OM and my obligations to my wife. I used to do about thirty trips a year. I have now reduced this to half.

The moral assent of the individual's close relations also represents a fundamental aspect to understanding why some members are more actively involved than others. The younger ones need their parents' support and authorization to contemplate membership. Additionally, active and regular attendance at matches requires a financial securing. This latter constraint is much stronger for those who are under eighteen or who are still at school or university. But we must concentrate on another dimension to understand the differentiated engagement of supporting at a distance. As Bromberger (1995, 345) emphasizes, "the paroxysmal passion for a club comes from a break in one's life". De facto, being actively involved in supporting at a distance constitutes a "remedial ritual" for a destiny that one feels slipping away. The transition from the status of 
basic member to that of active militant, sometimes including responsibilities, generally occurs during a specific stage of the life trajectory, notably when there are family, professional, or affective breaks and reorientations. The incidence of "biographical accidents" is essential. In this regard, Pierre (46 year-old male) is an exemplary illustration. As a member since 1997, he has travelled with the group almost every week to see OM play. He is the father of two children (who are also members), and got divorced five years ago:

In fact, I think the Rouen section has played a very big role for me. It enabled me to find a new family at a time I had lost mine in a way. I felt very bad, lonely. I could fight my way back again. It's obvious, I found a family and I was able to make it.

By creating a feeling of togetherness, the Rouen section acts as an intense space for sociability that breaks solitude, creates a field for discussion and shared emotions. The activism of football supporters thus frequently manifests itself after a collapse or a narrowing of perspectives in other spheres of social life: the professional sphere (the loss of a job), the domestic sphere (a divorce), and the sports sphere (an injury that shatters the dream of becoming a professional player). The involvement in supporting $\mathrm{OM}$ at a distance is attributable to a logic of identity affirmation in the sense that it is a social visibility vector (and more particularly in close surroundings, whether emotional or professional) as well as the opportunity to give back a life-enhancing "social reason". Hanging out with the group actively and regularly can therefore allow the reconstruction and reorientation of the identity in the long term.

New horizons arise for the active supporter. If the individual takes part in many trips, he can increase his responsibilities. This is how the assumption of responsibilities occurs within the group. Attaining this level is even more important if the individual is to expect new gratifications, i.e. numerous rewards with symbolic and identity connotations: benefits associated with a yearly subscription to the Stade Vélodrome (in Marseilles) and accruing from relations with members and managers of other groups of supporters at a distance, as well as recognition and acknowledgement when travelling to Marseilles. The intensive participation in the group constitutes a distinctive practice that brings with it a particular enhancement of status. Inclusion to this degree "means being accepted among those who are worthy of being part of the group and being qualified as a special person, or one of the best, if not a chosen one" (Signorelli, 1994, 622). Thus, the conditions for maintaining a long-term engagement are fulfilled.

At this juncture, the light has to be cast upon the effects of the involvement's length. All other aspects in other spheres of the social life tend to be organized around the supporter career. The latter progressively structures the professional or scholastic investments as well as all leisure activities, sociability and, sometimes, love affairs (McAdam, 1998). A process of identity conversion (Snow, 1993) happens and progressively shapes new frames of mind, new habits, and new behaviours. Therefore, the most involved supporters at a distance see their biography and identity spectacularly reconfigured. The new proximity with the inhabitants of Marseilles changes their sen- 
sibility, tastes, and preoccupations. They adopt their way of speaking (sometimes they even adopt the accent) and their way of life. The transformations multiply as the changes progress. This happens in the way they see things. Not only the club, but also the city itself becomes attractive and desirable. Marseilles represents a sweet dream made of sun, easy living, human contact and cosmopolitanism. ${ }^{4}$ The example of Alain (52 years-old male, member since 1997) perfectly illustrates this process. He is one of the "converted inhabitants of Rouen", and has been travelling to OM matches regularly for many years:

I dream of bringing my wife and children to Marseilles. I would like to offer the quality of life that is over there that cannot be compared to the one we have here, especially as regards the climate. I love this town. I really feel at home there. The people are not as withdrawn as they are here. They talk. There is such cosmopolitanism! I wish I had been born in Marseilles.

These supporters dream of Marseilles at a distance. They envy the lifestyle of the Marseillais, they are interested in the local life, they go there on holidays, and sometimes even plan to settle there, as Alain does. To sum up, once they have become accomplished OM supporters at a distance, they want to "become Marseillais". For these individuals, the personal and psychological involvement has become so important that the potential defection would be extremely costly. Leaving the group would mean losing many friends and relationships. But the engagement is never definitely guaranteed.

\section{Defections: leaving the group}

The idealized representations of the most fervent supporters at a distance are far from being shared by all. Such is the case for the least involved members. The picture they paint of Marseilles is, in this regard, more balanced and nuanced. Indeed, Paul (50 year-old male, member between 2000 and 2001) gives quite a different point of view:

The first time I saw Marseilles, I thought it looked like a poor city. You get the impression that everything is abandoned. It doesn't seem clean. It is a very superficial image, because I can't say I know Marseilles well. But when you see the high buildings from far away, when you arrive, the image is shocking (...). Maybe there are also areas that I don't know that are not like that. But I do think that it is a city where there must be a lot of poverty.

4 These naive and idealistic representations, stereotypes of the city and the inhabitants' life style are the consequence of an active involvement in supporting at a distance. Nevertheless, they cannot be considered as a sufficient trigger or motivation for the engagement. The supporters at a distance are not converted a priori. Marseilles and its inhabitants progressively fascinate them. This occurs during the conversion process. 
The vision of Marseilles that appears among the most recent members of the group and the least involved is thus somehow different. This divergence also occurs in the way they consider the distance supporter's activity. These differences within the representations, customs and practices lead us to consider the reasons of disengagement in the Rouen section. There are in fact many clashes. They come from the characteristic heterogeneity of the group. Such diversity can be explained by the succession of membership strata: the members did not all join the group at the same time in the history of the section. This results in a succession of different cohorts of militants who are situated at different levels of the career. This situation implies differences within the competences of all members. The newcomers' first incursions into the world of OM supporters reveal their relative ignorance of this universe. This sometimes occasions sour notes and faux pas. They neither master the conventions or the non-written norms, nor do they know the "codes". On the contrary, the most experienced members share the same language, and instantly empathize when they hear or talk about the same themes or memories. They share a common past and a collective memory and history.

These variations can generate some problems between the "well-established" and the new members. The ensuing tensions prevent a number of the latter from identifying with the group as it is represented. Defections therefore originate in the lack of fit between the profane expectations which these fans had acquired prior to joining the club and the practices and beliefs that are allowed and expected within the section. The older supporters marginalizing the novice or even excluding him can sanction this state of facts. But the tensions can also generate changes of positions among these supporters. The novices are accused of altering the initial spirit of the group, its atmosphere or even its reputation because they are considered unable sensitively to understand the life style, way of thinking and feeling of the "authentic" OM supporters. This logic is the main reason for the retreat of the oldest and most engaged members. This marginalization process can take different forms: keeping a distance with the section, being a dissident or "transferring" to another group, defecting or stopping active supporting.

\section{Conclusion}

Reconstructing each member's individual trajectory permits an understanding of the construction process of the distance supporter's career. To grasp the conditions and forms of going into action (whichever the type of involvement) fully, we must examine the temporal (and spatial) dimension of the social activity. Therefore, we must look not only into the primary socialization and the resulting system of trends but also into the logic of the supporter's career that can lead to a group such as the Rouen section. We have therefore been able to show that OM's supporters at a distance were not mere consumers who would have been influenced by television or targeted by the club's marketing strategies. The investment in this singular practice is neither the manifesttation of a social downgrading nor an answer to frustrations. The reasons pushing individuals to support a club actively in spite of the geographical distance are to be sought within the individual biographies. 
Thus, the family socialization, the diverse rewards resulting from participation in a collective action and the moments of rupture are essential in the various forms of engagement. Notably facilitating the acquisition of an individual notoriety capital, supporting at a distance appears as a possible form of "status enhancement" for the individual. At the end of the day, we are in a position to understand how and why these individuals who a priori had no or very little knowledge of the world of OM supporters and no affinity with Marseilles, not only adopt the local beliefs, discourses and cultural aspects, but also redefine their identity accordingly. The concept of career thus shows how the process of involvement with a cause - in this case, the support of OM - comes together with an ongoing transformation of identity (Strauss, 1993).

Eventually, this work suggests there is value in analysing supporting at a distance as a process. The engagement is not planned. We have to observe the way an individual becomes involved in the game. It is the result of a conjunction of tiny events, facts, situations and choices. The plans and the calculations build up throughout the action, not before.

\section{References}

Armstrong, G. \& Mitchell, J.-P. (1999). Making the Maltese Cross: Football on a Small Island. In G. Armstrong \& R. Giulianotti (Eds.), Football Cultures and Identities (99116). London: Macmillan.

Basson, J.-C. \& Nuytens, W. (2001). Modes d'encadrement et de contrôle des supporters de football, entre modèle officiel et alternative autonome: le cas du Racing club de Lens. Revue européenne du management du sport, 5, 1-29.

Becker, H. S. (1963). Outsiders, Studies in the Sociology of deviance. London: Free Press of Glencoe.

Ben-Porat, A. (2000). Overseas Sweetheart. Israelis Fans of English Football. Journal of Sport \& Social Issues, 24, 344-350.

Ben-Porat, G. \& Ben-Porat, A. (2004). (Un)Bounded Soccer. Globalization and Localization of the Game in Israel. International Review for the Sociology of Sport, 39 (4), 421436.

Boura, O. (2001). Marseille ou la mauvaise réputation. Paris: Arléa.

Bromberger, C. (1995). Le match de football. Ethnologie d'une passion partisane à Marseille, Naples et Turin. Paris: Maison des sciences de l'Homme.

Broqua, C. \& Fillieule, O. (2001). Trajectoires d'engagement. Paris: Textuel.

Brown, A. (1998). Fanatics! Power, Identity and Fandom in Football. London: Routledge.

Cobb, R. (2001). Marseille. Paris: Alia.

Crawford, G. (2003). The Career of the Sport Supporter: The Case of the Manchester Storm. Sociology, 37(2), 219-238.

Dunning, E., Murphy, P. \& Waddington, I. (2002). Fighting Fans: football hooliganism as a world phenomenon. Dublin: University College Dublin Press.

Fillieule, O. (2001). Propositions pour une analyse processuelle de l'engagement individuel. Revue française de science politique, 51(1-2), 199-215.

Gaxie, D. (1977). Economie et rétributions du militantisme. Revue française de science politique, 27 (1), 123-154. 
Giulianotti, R. (1999). Football: a Sociology of the Global Game. Cambridge: Polity.

Goksoyr, M. \& Hognestad, H. (1999). No longer worlds apart? British influences in Norwegian football. In G. Armstrong \& R. Giulianotti (Eds.), Football Cultures and Identities (201-210). London: Macmillan.

Haynes, R. (1995). The football imagination. The rise of football fanzine culture. Aldershot: Arena.

Hognestad, H. (2003). Long-Distance Football Support and Limital Identities Among Norwegian Fans. In N. Dyck \& E. Archetti (Eds.), Sport, Dance and Embodied Identities (97-114). Oxford: Berg.

Hornby, N. (1994). Fever Pitch. London: Penguin.

Hughes, E. C. (1937). Institutional Office and the Person. American Journal of Sociology XLIII, 409-410.

Hughes, E. C. (1996a). Carrières, cycles et tournants de l'existence. In E. C. Hughes (Ed.), Le regard sociologique. Essais choisis (165-173). Paris: EHESS.

Hughes, E. C. (1996b). Carrières. In E. C. Hughes (Ed.), Le regard sociologique. Essais choisis (175-185). Paris: EHESS.

Jones, I. (2000). A Mode of Serious Leisure Identification: The Case of Football Fandom. Leisure Studies 19 (4), 283-293.

Lahire, B. (2001). L'Homme pluriel. Les ressorts de l'action. Paris: Nathan.

Lestrelin, L. (2006). L'autre public des matches de football. Sociologie du supportérisme à distance. Le cas de l'Olympique de Marseille. Thesis, Faculty of Sport Sciences, University of Rouen.

Lestrelin, L. \& Basson, J.-C. (2004). Le supportérisme à distance: une forme d'identification aux clubs de football. In Société de sociologie du sport de langue française (Ed.), Dispositions et Pratiques sportives. Recherches et débats actuels en sociologie du sport (331-344). Paris: L'Harmattan.

Marsh, P. (1978). Life and Careers on the Football Terraces. In R. Ingham (Ed.), Football Hooliganism (61-81). London: Inter-Action Trust.

McAdam, D. (1998). Freedom Summer. Oxford: Oxford University Press.

Mignon, P. (1998). La passion du football. Paris: Odile Jacob.

Redhead, S. (1997). Post-fandom and the millenial blues: the transformation of soccer culture. London: Routledge.

Roversi, A. \& Balestri, C. (2000). Italian Ultras Today: Change or Decline? European Journal on Criminal Policy and Research 8, 183-199.

Sandvoss, C. (2003). A Game of Two Halves: Football, Television and Globalization. London: Routledge.

Signorelli, A. (1994). Territoires: les tifosi, l'équipe et la cité. Ethnologie française 25 (3), 616-628.

Smith, A. (2001). La passion du sport. Le football, le rugby et les appartenances en Europe. Rennes: Presses Universitaires de Rennes.

Strauss, A. L. (1959). Mirrors and Masks: The Search for Identity. London: The Free Press of Glencoe.

Strauss, A. L. (1993). Continual Permutations of Action. New York: Aldine de Gruyter. 
Tsoukala, A. (1995). Sport et violence. L'évolution de la politique criminelle à l'égard du hooliganisme en Angleterre et en Italie, 1970-1995. Athènes/Bruxelles: Sakkoulas/ Bruylant.

Williams, J. (2001). Into the Red. Liverpool and the Changing Face of English Football. Leicester: Mainstream Press.

Ludovic Lestrelin is doctor in Sport Sciences of the University of Rouen. He is an associate researcher at the Centre for the Study of Sports and Physical Activities' Transformations (contact: lestrelin_ludovic@yahoo.fr).

Loïc Sallé is doctor in Sports Sciences and a lecturer at the University Lille II. He is a researcher in the "sport, identity, culture" laboratory (contact: loicsalle@ yahoo.fr).

Jean-Charles Basson is doctor in Political Science and a lecturer at the University Paul Sabatier - Toulouse III. He is a researcher in the "sports, organizations, identities" laboratory (contact: basson@ cict.fr). 